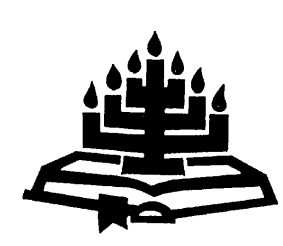

\title{
'n Teologies-etiese beoordeling van onwettige immigrasie
}

\author{
E.J. de Beer \\ Skool vir Kerkwetenskappe \\ Potchefstroomkampus \\ Noordwes-Universiteit \\ POTCHEFSTROOM \\ E-pos: edmunddebeer@lantic.net
}

Abstract

\section{A theological-ethical judgement of illegal immigration}

The immigration of people is a growing global phenomenon. People immigrate to South Africa mainly for economic purposes. Not all immigrants are, however, legally in the country. It is not certain how many illegal immigrants are in the country. The South African government does not have a clear, effective policy on how to solve the problem of illegal immigration. In this article the influence of illegal immigration on the South African labour sphere is analysed. The aim of the article is to give guidance from the Bible to role players on how their disposition should be concerning the problem of illegal immigrant workers. In the article the extent and causes of illegal immigration are investigated. This is followed by probing into the effects of illegal immigration on the South African labour sphere and the action taken by the authorities to solve the problem. The influence of illegal immigration on labour in South Africa is judged according to biblical principals. In the assessment guidance is given as to what the disposition of different role players should be concerning the set problem.

\section{Opsomming}

'n Teologies-etiese beoordeling van onwettige immigrasie

Immigrasie van mense is 'n wêreldwye toenemende verskynsel. Mense immigreer hoofsaaklik om ekonomiese redes na SuidAfrika. Nie alle immigrante is egter wettig in die land nie. Dit is nie duidelik hoeveel onwettige immigrante in Suid-Afrika is nie. Die Suid-Afrikaanse regering het geen duidelike, doeltreffende beleid oor hoe om die probleem van onwettige immigrante op te los nie. In hierdie artikel word die invloed van onwettige immi- 
grasie op die Suid-Afrikaanse arbeidsterrein ondersoek. Die doel van die studie is om aan rolspelers vanuit die Bybel leiding te gee oor hoe hulle ingesteldheid teenoor die probleem van onwettige immigrantwerkers behoort te wees. In die artikel word die omvang en oorsake van onwettige immigrasie ondersoek. Daarna val die soeklig op die gevolge van onwettige immigrasie op die Suid-Afrikaanse arbeidsterrein en die optrede van die owerheid om die probleem hok te slaan. Dit word gevolg deur die bestudering van 'n aantal tersaaklike bybelse uitsprake. Die invloed van onwettige immigrasie op die Suid-Afrikaanse arbeidsterrein word in die lig van die bybelse uitsprake beoordeel. In die beoordeling word leiding aan verskillende rolspelers gegee oor hoe hulle ingesteldheid teenoor die gestelde probleem behoort te wees.

\section{Inleiding}

Die xenofobies-verwante aanvalle op buitelanders gedurende Mei 2008 het die soeklig skerp laat val op die teenwoordigheid van immigrante in Suid-Afrika. Die aanvalle het die volgende tipe vrae na vore gebring: Het onwettige immigrante die reg om beskerm te word wanneer hulle wettige landsburgers oënskynlik geleenthede om te werk ontneem?; Wat is die invloed van onwettige immigrante op die Suid-Afrikaanse arbeidsterrein?; Is dit reg om onwettige immigrante te deporteer terwyl hulle in ander opsigte landswette gehoorsaam en 'n positiewe bydrae tot die land se ekonomie lewer?; Hoe moet teenoor onwettige immigrante opgetree word?

In hierdie artikel word die invloed van onwettige immigrasie op die Suid-Afrikaanse arbeidsterrein ondersoek met die oog daarop om die invloed van onwettige immigrasie teologies-etiese te beoordeel.

Die omvang en oorsake van onwettige immigrasie word eerstens gestel. Daarna word ondersoek ingestel na die gevolge van onwettige immigrasie op die arbeidsterrein, gevolg deur die vasstelling van teologies-etiese beginsels wat op onwettige immigrasie betrekking het. Onwettige immigrasie se invloed op die Suid-Afrikaanse arbeidsterrein word laastens in die lig van die vasgestelde beginsels beoordeel.

\section{Oriëntering}

Wêreldwyd woon 175 miljoen mense buite die grense van hulle lande van oorsprong, meer as dubbeld die hoeveelheid as 'n geslag gelede (Williams \& Carr, 2006:1). Die omvang van hierdie groei word duideliker wanneer in aanmerking geneem word dat internasio- 
nale immigrante in Afrika van 9 miljoen in 1960 tot 16 miljoen in 2000 toegeneem het. In hierdie opsig is suidelike Afrika nie uniek nie. Ongeveer 0,6\% van die inwoners van suidelike Afrika is internasionale immigrante. In Wes- en Oos-Afrika is die persentasie internasionale immigrante onderskeidelik $2,7 \%$ en $1,8 \%$ (Crush \& Williams, 2004:1, 2).

Immigrasie in verskillende streke van Afrika toon kenmerkende patrone. Vanuit Wes- en Sentraal-Afrika vind arbeidsimmigrasie na die ontwikkelde lande en olieryke golfstate plaas. In Oos- en Wes-Afrika is baie vlugtelingimmigrasie en in die oostelike en suidelike dele van die kontinent is arbeidsimmigrasie na Suid-Afrika kenmerkend (Adepoju, 2006:25). Namate vervoer en kommunikasie goedkoper en meer gesofistikeerd raak, kan internasionale immigrasie verder groei (Williams \& Carr, 2006:1).

Die regeringsverandering van 1994 tesame met die wêreldwye globalisasieproses het tot gevolg dat vryer immigrasie na Suid-Afrika plaasvind. Globalisasie veroorsaak dat kapitaal, inligting, tegnologie en mense nie meer deur grense ingeperk word nie. Laasgenoemde manifesteer in 'n toenemende getal toeriste, sakemanne, vlugtelinge en onwettige immigrante wat na Suid-Afrika toe kom (SA, 1999:4; Akokpari, 2007:65).

Hoewel die aantal immigrante na Suid-Afrika die afgelope twee dekades baie toegeneem het, is immigrasie na Suid-Afrika geen nuwe verskynsel nie. Werkers immigreer die afgelope 150 jaar reeds na Suid-Afrika (Crush et al., 2006:3, 14).

\section{Definisie}

Daar word soms na onwettige immigrante (illegal immigrants) verwys as ongedokumenteerde migrante (undocumented migrants), migrante sonder toestemming (unauthorised migrants) of ongeoorloofde migrante (irregular migrants) (Crush et al., 2006:14; Waller, 2006:1). Die Immigrasiewet (SA, 2002) gebruik die term onwettige vreemdeling (illegal foreigner) in plaas van onwettige immigrant. Volgens die wet is 'n onwettige vreemdeling 'n persoon wat nie 'n burger of inwoner van Suid-Afrika is nie en wat strydig met die Immigrasiewet in die land is. ' $n$ Vreemdeling wat die land sonder behoorlike toestemming of op 'n korrupte manier binnegekom het, of 'n vreemdeling wat in die land aanbly nadat sy visum of permit verval het, of 'n vreemdeling wat hom/haar besig hou met aktiwiteite anders as wat sy permit toelaat, is volgens hierdie wet 'n onwettige vreemdeling (Waller, 2006:1). 
In Afrikaans word die term onwettige immigrant eerder as onwettige vreemdeling gebruik. In hierdie artikel word eersgenoemde term gebruik vir 'n persoon wat Suid-Afrika binnegekom het en wat strydig met die Immigrasiewet (SA, 2002) in die land is.

\section{Omvang van onwettige immigrasie}

Dit is uiters moeilik om die omvang van onwettige immigrasie na Suid-Afrika te bereken, omdat daar nie betroubare statistiek hieroor is nie. As gevolg van agterdog is onwettige immigrante geneig om nie aan sensusopnames deel te neem nie (Hirschowitz, 2001:14).

Posel (2003:5) wys daarop dat die Suid-Afrikaanse Polisiediens in 1995 gereken het dat daar tussen 5,5 en 8 miljoen onwettige immigrante in die land was, terwyl die Departement van Binnelandse Sake gereken het dat daar ongeveer 4 miljoen onwettige immigrante was. Dit is onduidelik hoe enige van hierdie syfers bereken is (Landau, 2005:3). Crush et al. (2006:15) van die Southern African Migration Project reken dat 2-3\% (500 000 mense) van die land se inwoners onwettige immigrante is.

Hoewel daar geen betroubare statistiek oor die aantal persone beskikbaar is wat die land jaarliks onwettig binnekom, of reeds onwettig in die land woon nie, is daar wel statistiek beskikbaar oor die getal mense wat jaarliks gerepatrieer word. In 2004 het die Departement van Binnelandse Sake 167137 mense wat onwettig in die land was, gedeporteer. Hiervan was 81619 uit Mosambiek, 72112 uit Zimbabwe en 7468 uit Lesotho afkomstig (Waller, 2006:2). Dit blyk dat die getal onwettige immigrante toeneem. Dit hou veral verband met swak ekonomiese en politieke toestande in Zimbabwe. Gedurende die eerste sewe maande van 2007 is 117737 onwettige immigrante na Zimbabwe gedeporteer (IRIN, 2007).

Tussen 1990 en 1997 het 97\% van die onwettige immigrante wat gedeporteer is uit lande van die Suider-Afrikaanse Ontwikkelingsgemeenskap (SAOG) gekom en 0,1\% van ander Afrikalande. Vanaf ongeveer 2000 het die deportasie van persone na lande buite Afrika egter merkbaar toegeneem. Pakistan (1325), Indië (808), China (480), die Verenigde Koninkryk (205), Bangladesh (201), Turkye (178) en Thailand (118) is die lande waarna die meeste mense gedeporteer is (Waller, 2006:3).

Die berekening van die getal onwettige immigrante word bemoeilik deur die sogenaamde wenteldeur-sindroom. 'n Onbekende aantal persone wat gedeporteer word, keer na 'n tyd weer terug. Sommige 
waarnemers meen dat die deportasie van onwettige immigrante vrugteloos is en moontlik selfs onwettige immigrasie aanmoedig (Waller, 2006:4).

\section{Wyses van binnekoms}

Daar is verskeie maniere waarop onwettige immigrante die land binnekom. Sommige persone kom die land onwettig binne en bly dan onwettig hier. Suid-Afrika se grense is 7000 km lank en kan maklik oorgesteek word. In 1994 en 1995 het die Suid-Afrikaanse Nasionale Weermag 47031 mense gevange geneem wat die grense onwettig oorgesteek het. Daarvan het $65 \%$ die Mosambiekse grens en $28 \%$ die Zimbabwiese grens onwettig oorgesteek (SAMP, 2001: 15).

'n Tweede groep onwettige immigrante kom die land wettig binne, maar bly dan onwettig aan. Berekenings dui daarop dat daar in die periode vanaf 1990 tot Maart 1997 nie minder nie as 658875 persone die land wettig ingekom het, maar hulle verblyfpermitte het reeds verval (SAMP, 2001:17). In 1998 was daar reeds na beraming 75000 Zimbabwiërs wat op hierdie manier in Suid-Afrika gewoon het (Tevera \& Zinyama, 2002:20).

'n Gebrek aan hulpbronne en onbekwaamheid van werknemers in die Departement van Binnelandse Sake speel ook 'n rol waarom sommige immigrante die land wettig kan binnekom, maar met verloop van tyd onwettig in Suid-Afrika is (Waller, 2006:5). In hierdie verband kan na ongeveer 20000 asielsoekers verwys word wat die land jaarliks binnekom. Terwyl hulle aansoeke verwerk word, mag hulle nie werk nie. Aangesien hulle gedurende hierdie tyd nie voldoende materiële hulp ontvang nie, word hulle gedwing om ter wille van oorlewing te werk en word dan as onwettige immigrante beskou (Handmaker, 2002:2, 14).

'n Derde groep onwettige immigrante is diegene wat Suid-Afrika onwettig binnekom, maar dan wettig in die land aanbly. Hierdie immigrante sluit nie vlugtelinge, asielsoekers, suksesvolle aansoekers van die 1996-immigrasie-amnestie en onwettige immigrante wat vir werksdoeleindes gewettig is, in nie (SAMP, 2001:17).

Daar is ook persone wat die land met vervalste dokumente inkom. Veral persone uit China, Pakistan en Nigerië is hieraan skuldig. Onwettige immigrante misbruik die laat-registrasie van geboortes en die registrasie van vals huwelike om Suid-Afrikaanse burgerskap te 
verkry. Persone uit veral Pakistan, Indië, Egipte en Nigerië is hierby betrokke (Waller, 2006:4, 5).

\section{Oorsake van onwettige immigrasie}

Oorgrensmigrasie kom reeds jare lank algemeen in suidelike Afrika voor. Tot $42 \%$ van die inwoners van Zimbabwe, Mosambiek en Lesotho het Suid-Afrika minstens een keer besoek. Een of albei ouers van diegene wat Suid-Afrika besoek het, was ook al in die land asook 34\% van hulle grootouers (McDonald et al., 1998:9).

Die beëindiging van apartheid en die opname van Suid-Afrika in die Suider-Afrikaanse Ontwikkelingsgemeenskap (SAOG) het daartoe gelei dat daar 'n groot toename in die wettige en onwettige immigrasie van persone na Suid-Afrika is. Die land se hertoetrede tot die internasionale arena en globalisasie bevorder immigrasie (Crush et al., 2006:2). Globalisasie is een van die hoofdryfvere vir die totstandkoming van die groepering in streeksekonomieë en gemeenskaplike markte soos byvoorbeeld die Europese Unie (EU), die Ekonomiese Gemeenskap van Wes-Afrikastate (Ecowas) en die Suider-Afrikaanse Ontwikkelingsgemeenskap (SAOG). Hierdie ekonomiese gemeenskappe vergemaklik immigrasie tussen die onderskeie ledelande (Akokpari, 2007:66).

Apartheid is in dieselfde tyd beëindig as wat die SAOG ontstaan het. Die ekonomies-vooruitstrewende postapartheid Suid-Afrika het vir baie inwoners in die sub-Saharalande 'n aanloklike bestemming geword (Akokpari, 2007:66), omdat ontwikkeling in baie sub-Saharalande gekniehalter word deur makro-ekonomiese aanpassings, omvangryke armoede, die veragtering van mense, die agteruitgang van bevolkings se algemene welstand en uitermate hoë skuld. Lande suid van die Sahara bestee byna twee derdes van hulle uitvoerverdienste aan skulddelging. Gevolglik het regerings min fondse vir sosio-ekonomiese ontwikkeling en die skep van nuwe werksgeleenthede (Adepoju, 2006:26).

Die meeste onwettige immigrante kom om ekonomiese redes na Suid-Afrika. 'n Studie in 1998 het aangetoon dat slegs 16\% van die buitelanders 'n behoefte gehad het om permanent in Suid-Afrika te bly, terwyl $45 \%$ laat blyk het dat hulle vir 'n tydperk in die land wil bly (SAMP, 2001:13, 14); 24\% het 'n behoefte aan Suid-Afrikaanse burgerskap; $18 \%$ wil in Suid-Afrika aftree; $9 \%$ wil hier begrawe word; en slegs $17 \%$ sal wil hê dat hulle kinders hulself as Suid-Afrikaners beskou (McDonald et al., 1999:28). Die buitelanders gebruik SuidAfrika as 'n plek waar hulle noodsaaklike lewensmiddele vir hulself 
en hulle afhanklikes kan verdien. Inwoners uit ander Suider-Afrikaanse state immigreer graag na Suid-Afrika, met die oog op beter beroepsgeleenthede, beter inkomste, laer belasting en toegang tot die maatskaplike ondersteuningstelsels (Campbell, 2002). Die swak ekonomiese en politieke toestande in Zimbabwe die afgelope paar jaar veroorsaak dat al hoe meer onwettige immigrante uit daardie land Suid-Afrika binnekom (IRIN, 2007).

Die vasstelling van landsgrense sonder inagneming van die bewoning van gebiede deur plaaslike inwoners, speel ook 'n rol in die bevordering van onwettige immigrasie. Mense kruis grense dikwels vir sakedoeleindes, om familielede te besoek of skole by te woon (Waller, 2006:4, 5).

Die oorloë in Angola en Mosambiek het veroorsaak dat duisende mense geëmigreer het, ook na Suid-Afrika toe. Die emigrasie wat destyds plaasgevind het, het vandag nog steeds 'n uitwerking (Crush et al., 2006:2).

Baie immigrante kom om politieke redes na Suid-Afrika. Politieke en sosiale onrus in Rwanda, Soedan, Somalië, Nigerië, die Demokratiese Republiek van die Kongo, Burundi en Zimbabwe tesame met die afskaffing van reisboikotte na Suid-Afrika ná 1990, het immigrasie na die land laat toeneem (Crush \& Williams, 2004:6). Die lae lewenstandaard, hoë werkloosheid en ekologiese agteruitgang in lande suid van die Sahara is ook faktore wat immigrasie bevorder (Waller, 2006:6). Suid-Afrika is 'n gewilde bestemming, omdat hierdie land as redelik vreedsaam beskou word en die persepsie bestaan dat daar baie werksgeleenthede is (Crush \& Williams, 2004:6; SAMP, 2001:4, 5).

Suid-Afrika is deel van ' $n$ internasionale smokkelnetwerk van vroue en kinders uit onder meer Mosambiek, Lesotho, Thailand, China en Oos-Europa. Vlugtelinge wat reeds in Suid-Afrika gevestig is, speel 'n sleutelrol om hierdie onwettige immigrante na die land te lok (Adepoju, 2006:35).

Moderne kommunikasiemiddels bevorder onwettige immigrasie. Inligting oor plekke waar werk in die land beskikbaar is, word maklik versprei (Waller, 2006:5). Suid-Afrikaanse werkgewers neem graag buitelanders in diens, omdat die werkgewers meen dat hulle meer produktief en meer gedissiplineerd is, beter vaardighede het, eerlik is en minder militant is (Rogerson, 1999:4; SAMP, 2001:8). 
Daar is ook onwettige immigrante wat Suid-Afrika as aankoopmark gebruik, met die oog op die herverkoop van goedere elders in Afrika. Die helfte van die handelaars uit Afrika (en meer as driekwart uit die SAOG) bestee die grootste deel van hulle winste in Suid-Afrika met die aankoop van goedere om dit buite die land se grense te gaan verkoop (Carter \& Haffajee, 1998).

\section{Gevolge van onwettige immigrasie}

Onwettige immigrasie het op verskillende vlakke 'n invloed op die Suid-Afrikaanse arbeidsterrein. Die negatiewe gevolge kom eerste onder die soeklig en daarna volg die positiewe gevolge.

Die Witskrif op Internasionale Migrasie (SA, 1999:6) meld dat onwettige immigrante:

- met arm Suid-Afrikaners meeding vir skaars hulpbronne, openbare dienste soos skole, mediese sorg, infrastruktuur, grond, behuising en informele handelsgeleenthede;

- met plaaslike inwoners meeding vir die beperkte aantal werksgeleenthede en is bereid om vir minder as die voorgeskrewe wetlike voorwaardes of die voorwaardes van bedingingsooreenkomste te werk;

- die staat en sy organe verswak deur amptenare om te koop, op korrupte maniere dokumente en regte te verkry en die land se beeld plaaslik en in die buiteland te skaad.

Aangesien daar geen duidelikheid is oor hoeveel onwettige immigrante in die land is nie, maak dit die beheer en bestuur van immigrasie, hulpbronne, maatskaplike dienste, veiligheid en die ontwikkeling van die ekonomie en infrastruktuur moeilik (Waller, 2006: 1). 'n Ondersoek onder immigrante in 1998 het bevind dat $96 \%$ van die immigrante dieselfde toegang as Suid-Afrikaanse burgers tot gesondheidsorg wil hê, en onderskeidelik $93 \%, 79 \%$ en $79 \%$ dieselfde toegang tot opvoeding, huisvesting en werksgeleenthede wil hê (McDonald et al., 1999:25).

Onwettige immigrante wek negatiewe emosies by Suid-Afrikaners op. In 1997 het die Raad vir Geesteswetenskaplike Navorsing (RGN) bevind dat $65 \%$ van die respondente onwettige immigrasie sterk veroordeel het, omdat hulle meen dat buitelandse werkers Suid-Afrikaners van werksgeleenthede beroof. Die teenwoordigheid van immigrante, veral onwettige immigrante, veroorsaak wantroue, vyandigheid en xenofobie (Akokpari, 2007:71-72). Dit het al tot aan- 
valle op smouse, die afbrand van immigrante se wonings en polisiemishandeling gelei (Adepoju, 2006:36).

Sommige onwettige immigrante is betrokke by kriminele aktiwiteite. Dit sluit die smokkel van grysprodukte, dwelms, diamante, goud, perlemoen, ivoor, renosterhoring, mense, voertuigkapings, geldwassery en die ontduiking van belasting in (Waller, 2006:7).

Onwettige immigrante benadeel die Suid-Afrikaanse ekonomie ook op 'n ander manier, naamlik dat dit die Suid-Afrikaanse belastingbetaler R25 per dag kos aan huisvesting en voedsel vir elke onwettige immigrant wat op repatriasie wag (Lekota \& Mpye, 2000:3). Die Departement van Binnelandse Sake bestee jaarliks R35 miljoen aan die repatriasie van onwettige immigrante (Molakeng, 2001:12).

Die immigrasie van (onwettige) werkers uit ander lande is soms tot voordeel van Suid-Afrika, maar tot nadeel van die lande waaruit hulle emigreer. As voorbeeld kan genoem word dat $60 \%$ van Zimbabwe se dokters na Botswana en Suid-Afrika geïmmigreer het. Waar hoogs gekwalifiseerde werknemers hulle lande van oorsprong verlaat en onwettig na Suid-Afrika immigreer, is dit tot nadeel van hulle geboortelande en tot voordeel van Suid-Afrika (Adepoju, 2007:29).

Onwettige immigrante lewer dikwels ook op ander maniere 'n positiewe bydrae tot die Suid-Afrikaanse ekonomie deur dienste wat hulle lewer. Die meeste onwettige immigrante werk vir hulleself, hoofsaaklik in die informele sektor. Hulle verkoop vrugte, klere en ander goedere op straat. Ander het klein besighede waar hulle sweiswerk doen, haarkappery beoefen en kleinhandel bedryf (Crush \& Williams, 2004:6).

Tot $70 \%$ van straathandelaars bring goedere uit hulle lande van herkoms saam om in Suid-Afrika te verkoop. Dit sluit curios en kossoorte in wat nie vryelik in Suid-Afrika beskikbaar is nie (Peberdy $\&$ Crush, 1998:22). Plaaslike straathandelaars verwelkom buitelanders se betrokkenheid in die handel, omdat dit hulle aan nuwe produkte en sakemoontlikhede blootstel (Landau, 2005:13). Immigrante dra ook ' $n$ belangrike deel by tot die oorlewing van die Suid-Afrikaanse mynbedryf, 'n belangrike deel van die Suid-Afrikaanse ekonomie (Akokpari, 2007:72).

Tot $56 \%$ van die buitelandse straathandelaars neem handelsware saam na hulle lande van herkoms om daar te verhandel wanneer hulle (van tyd tot tyd) huis toe gaan. Hulle betaal BTW op die ware wat hulle uitvoer. Die winste wat die handelaars maak, word weer in 
die Suid-Afrikaanse ekonomie belê wanneer nuwe aankope gedoen word (Peberdy \& Crush, 1998:23-25). Dit dra indirek by tot werkskepping in Suid-Afrika (Peberdy \& Crush, 1998:7).

Sommige onwettige immigrante dra direk tot werkskepping by. Immigrante entrepreneurs skep gemiddeld 3,33 werksgeleenthede per onderneming. Tussen $40 \%$ en $50 \%$ van die werksgeleenthede gaan na Suid-Afrikaners. Immigrante entrepreneurs neem persentasiegewys meer werkers in diens as hulle Suid-Afrikaanse eweknieë (Rogerson, 1997:14; Landau, 2005:13).

Deur gedeeltes van hulle winste na hulle huise in die land van hulle herkoms te kanaliseer (remittances) waar dit onder meer gebruik word vir gesondheidsorg, die opvoeding van familielede en om ondernemings daar uit te bou, is dit tot voordeel van daardie lande se ekonomieë en verlig dit waarskynlik die druk op toekomstige immigrasie na Suid-Afrika (Adepoju, 2006:31; Peberdy \& Crush, 1998:7). Die bedrag geld wat immigrante na hulle lande van oorsprong stuur, is so groot dat dit naas die direkte beleggings vanuit die buiteland die grootste bydraer van kapitaal in ontwikkelende lande is (Akokpari, 2007:59).

Gesien vanuit 'n makro-ekonomiese oogpunt, is daar voordele wanneer onwettige immigrante onder die vlak van die vasgestelde arbeidswetgewing werk. Hulle bring buigbaarheid in 'n arbeidsmark wat toenemend rigied raak. Onwettige werkers bevorder ekonomiese groei deur ondernemings aan die gang te hou wat andersins, as gevolg van arbeidskoste, tot niet sou gaan (SA, 1999:6).

\section{Optrede teen onwettige immigrasie}

$\mathrm{Na}$ die regeringsverandering van 1994 is verskeie optredes geloods om die onwettige immigrasieprobleem op te los.

Sommige onwettige immigrante wat jare lank in Suid-Afrika gewoon en gewerk het, het geleentheid gekry om vir amnestie aansoek te doen en permanente verblyfreg in Suid-Afrika te ontvang. In 1995 is aan 50000 persone wat sedert 1986 vir Suid-Afrikaanse myne gewerk het, amnestie verleen. In 1996 het 125000 onwettige immigrante uit SAOG-lande en in 1999-2000 'n verdere 90000 Mosambiekers verblyfreg ontvang (Waller, 2006:9).

Die toestaan van amnestie was eenmalige vergunnings. Die SuidAfrikaanse regering probeer onwettige immigrasie hoofsaaklik deur die repatriasie van onwettige immigrante bekamp. In totaal word na 
beraming 180000 persone jaarliks gerepatrieer. Daarvan word 99,5\% na SAOG-lande gestuur (McDonald et al., 1999:13; Molakeng, 2001:12). Ten spyte van die groot aantal persone wat jaarliks na hulle land van herkoms teruggestuur word, lyk dit nie baie effektief te wees nie (vgl. Bhengu, 2000:3). As gevolg van te min personeel en 'n te klein begroting kan dit tot 44 jaar neem om al die onwettige immigrante te repatrieer (Anon., 2000:4).

'n Hoofimmigrasiebeampte van die Departement van Binnelandse Sake het ook al laat blyk dat die regering nie ernstig is om onwettige immigrante uit die land te hou nie. Klaarblyklik word niks gedoen om heinings aan die landsgrense waardeur onwettige immigrante die land binnekom, te herstel nie (Anon., 2002:10). Die Menseregtekommissaris meen dat deportasie slegs ' $n$ vermorsing van belastinggeld is (Matsena, 2002:6).

Benewens die deportasie van onwettige immigrante, ontmoedig die Departement van Binnelandse Sake onwettige immigrasie deur die kriminalisering van handel in mense, die nie-erkenning van vervalste huwelike, die uitreiking van boetes, die deurgee van inligting aan oorsese missies en die opleiding van immigrasiebeamptes om vervalste paspoorte, visums en permitte te herken (Waller, 2006:9).

Die Departement van Binnelandse Sake probeer onwettige immigrasie teenwerk deur werkgewers te ontmoedig om onwettige immigrante in diens te neem. Die Departement van Arbeid beskou optrede teen werkgewers wat onwettige immigrante in diens neem as ' $n$ manier om toe te sien dat die basiese arbeidsvereistes nagekom word. Die Departement reken dat optrede teen sulke werkgewers arbeidstandaarde sal verhoog en werkgewers gevolglik sal ontmoedig om onwettige immigrante in diens te neem (Crush \& Williams, 2001:19). Werkgewers wat onwettige immigrante in diens neem, kan met tot R40 000 beboet word vir elke onwettige immigrant aan wie werk verskaf word. In 2000 is 'n Kaapstadse sakeman met R120 000 beboet, omdat hy verskeie onwettige immigrante in diens gehad het (Molakeng, 2001:12).

In 2002 het die Instituut vir Sekerheidstudie die burokratiese en tegniese kontrole van onwettige immigrante verwerp. Die Instituut beveel aan dat oplossings eerder moet fokus op streek-, nasionale-, provinsiale- en plaaslike herkonstruksie, werkskepping en ekonomiese groei (Waller, 2006:9). Die Ontwerp Groenskrif op internasionale migrasie (SA, 1997:11) stel voor dat bona fide ekonomiese immigrante uit die SAOG wat nie permanent in Suid-Afrika wil vestig 
nie, groter geleentheid kry om wettig in die arbeidsmark deel te neem.

\section{Bybelse perspektiewe}

Voordat onwettige immigrasie en die invloed daarvan op die SuidAfrikaanse arbeidstoneel teologies-eties beoordeel word, is dit nodig om eers riglyne uit die Bybel vas te stel, aan die hand waarvan die beoordeling gedoen kan word. In die Bybel is talle uitsprake oor werk en oor vreemdelingskap wat in ag geneem moet word. Uit die bybelse uitsprake en opdragte wat God duisende jare gelede oor werk en vreemdelingskap gegee het, word onderliggende beginsels afgelei om die teenswoordige probleem van onwettige immigrasie te beoordeel.

Saam met die opdrag om die aarde te bewerk (Gen. 1:28), het die mens ook die opdrag ontvang om die aarde te bewoon, letterlik te vul. Die opdrag om die aarde te bewoon, is ten nouste verbind aan die opdrag om die aarde te bewerk (Gen. 1:28). Die opdrag om die aarde te bewoon, hou in beginsel in dat die mens die reg het om op enige plek op die aarde te woon. Hierdie reg kan hy alleen uitoefen as hy die samehangende opdrag (om die aarde te bewerk) uitvoer. In beginsel het 'n persoon die reg om te werk waar hy woon (vgl. De Beer, 2004:126-128).

Die opdrag om die aarde te bewoon en te bewerk, is na die sondeval herhaal toe Noag en sy seuns die opdrag gekry het om vrugbaar te wees en die aarde te bewoon (Gen. 9:1-3). Die diere en groen plante sou hulle voedsel wees. Om die voedsel te benut, moes hulle werk.

Die implikasie van bogenoemde is dat die mensdom oor die hele aarde werksaam sou wees. Aanvanklik wou die mensdom nie oor die hele aarde woon nie, maar God het hulle gedwing om oor die aarde te versprei (Gen. 11:1-9). Nuwe gemeenskappe en owerheidstrukture het ontwikkel. Dit het egter nie beteken dat mense permanent in gemeenskappe gebly het nie. Individue of groepe mense het steeds bly rondtrek as gevolg van onder meer oorloë, hongersnood, pes en bloedskuld. Hulle is vreemdelinge genoem. Vreemdelinge se reg om grond te besit, te trou, beskerming te geniet, deel te neem aan godsdiens en oorloë is ingekort (Holladay, 1971:64). Abraham was so 'n vreemdeling in Hebron (Gen. 23:4), Moses in Midian (Eks. 2:22) en Elimeleg in Moab (Rut 1:1). 
God het die mens geskep en aan hom lewe gegee. Hierdie lewe hou die mens in stand wanneer hy die arbeidsopdrag (Gen. 1:28) getrou nakom. Omdat God bepaal het dat die mens van die vrug van sy arbeid sal leef, het elke mens in beginsel die reg om te werk sodat hy kan leef (De Beer, 2008:34). Hierdie beginsel geld ook vir vreemdelinge. Hulle is immers ook deur God geskep en moet ook die arbeidsopdrag uitvoer.

Vreemdelinge was vanweë die aard van hulle omstandighede reeds in die bybelse tyd 'n maklike prooi vir uitbuiting. God het besondere maatreëls ingestel om sulke uitbuiting en onderdrukking te voorkom (Eks. 22:21; Lev. 19:33). Die rede waarom die Israeliete met besondere bewoënheid teenoor vreemdelinge moes optree, was omdat hulle self tydens hulle verblyf in Egipte vreemdelinge was (Eks. 22:21; Lev. 19:33). Omdat God vreemdelinge liefhet, moes hulle ook vreemdelinge liefhê (Deut. 10:18), reg teenoor hulle laat geskied en hulle nie uitbuit nie. Dit het ook uitbuiting op arbeidsgebied ingesluit. Vreemdelinge wat vir die Israeliete gewerk het, mag byvoorbeeld, soos hulle werkgewers, net ses dae 'n week gewerk het, sodat hulle die sewende dag kon rus (Eks. 23:12; Deut. 5:14). Onderliggend aan die beskermende maatreëls wat vir vreemdelinge gegeld het, is God se besorgdheid vir weerlose mense. Dit is 'n beginsel wat vandag steeds geld.

Hoewel vreemdelinge besonder uitgelewer was en daarom ook reg gehad het op bystand (vgl. Deut. 10:18, 19; 14:28, 29), het dit nie beteken dat hulle nie hoef te gewerk het nie. Die beginsel dat die werker van die vrug van sy arbeid sal leef, het ook vir hulle gegeld. Vreemdelinge het dieselfde geleenthede as weduwees en weeskinders gekry, naamlik om die oorblyfsels van oeste op die landerye, olyfbome en wingerde te oes (Lev. 19:9-10; 23:22; Deut. 24:19-21). Aan hulle is die geleentheid gebied om te kan werk en die vrug van hulle arbeid te geniet. Hulle het egter nie dieselfde regte en voorregte as 'n land of streek se inwoners geniet nie. In Israel het vreemdelinge byvoorbeeld nie soos die Israeliete grond besit nie. Hulle was oor die algemeen arm en moes vir die Israeliete werk (MartinArchard, 1984:410). Daar was egter ook uitsonderings. Vreemdelinge kon so welvarend raak dat hulle soveel krediet kon verskaf dat Israeliete hulleself moes verslaaf om hulle skuld af te los. God het die materiële vooruitgang van vreemdelinge nie verbied nie, maar wel maatreëls ingestel oor hoe Israeliete mekaar moes bystaan om vry te kom van die verslawing aan vreemdelinge, sonder dat die vreemdelinge materieel benadeel is (Lev. 25:47-55). 
Uit hierdie maatreëls kan afgelei word dat hoewel daar ten opsigte van die alledaagse lewe geen onderskeid tussen vreemdelinge en die burgers van ' $n$ land is nie (vgl. Vorster, 2004:168), die owerheid die reg het om maatreëls in te stel wat die burgers van 'n land teen buitelanders beskerm. Die maatreëls moet egter van so 'n aard wees dat buitelanders nie weerloos gelaat word nie.

In die Ou en Nuwe Testament word die benadeling van weerlose, arm mense sterk veroordeel. In Jesaja 10:1-2 word diegene wat armes hulle reg ontsê en wat die weerloses uitbuit, veroordeel. Ook in Amos 4:1-3 word diegene wat swakkes verdruk en armes mishandel, veroordeel. In die Nuwe Testament word hierdie tema veral in Jakobus voortgesit. In Jakobus 1:27 word daarop gewys dat "Egte en suiwer godsdiens voor God die Vader is om weeskinders en weduwees in hul moeilike omstandighede by te staan ...". Weeskinders en weduwees is kategorieë mense wat in die Ou Testament in dieselfde asem as vreemdelinge genoem is (vgl. Deut. 24:19-21). In Jakobus 2:10, 13 word gewaarsku teen diskriminasie teen mense bloot op grond van hulle materiële vermoëns en stand in die samelewing. Sulke optrede is strydig met die liefdesgebod (Pretorius, 1988:53-54).

Die Ou-Testamentiese beginsels rakende die versorging van armes, weduwees en vreemdelinge is in die Nuwe-Testamentiese kerk toegepas. Toe die Griekssprekende weduwees in die Jerusalemse gemeente nie behoorlik versorg is nie, is buitengewone maatreëls getref om na hulle basiese behoeftes om te sien (Hand. 6:1-7). Die Griekssprekende Jode was in 'n sekere sin ook vreemdelinge. Hulle was waarskynlik Jode wat in die diaspora gewoon en op gevorderde leeftyd in Jerusalem kom woon het (De Villiers, 1977:122). Nog 'n voorbeeld van hulpbetoon is Tabita, die gelowige vrou van Joppe. Sy is bekend, omdat sy "altyd besig was om goed te doen en die armes te help" (Hand. 9:36). Die verskaffing van hulp aan weerloses in die samelewing is 'n beginsel wat steeds geld.

In beginsel het enige werker die reg om enige plek op aarde te woon, te werk en daarvoor vergoed te word. Hierdie reg is nie losstaande van die organisasie en reëlings wat owerhede op 'n plek of in 'n land het nie. Dit is die owerheid se plig om tot die beswil van sy onderdane te regeer (Rom. 13:4). Dit impliseer dat elke owerheid sekere maatreëls sal tref, om te verseker dat die onderdane die geleentheid sal hê om te werk en in hulle eie behoeftes te voorsien. Die owerheid van 'n land het egter ook 'n besondere plig om die wettige burgers van 'n land te beskerm. Dit sluit beskerming teen die nadelige invloed van onwettige immigrante in, maar dit beteken nie 
dat die owerheid onmenslik teenoor vreemdelinge kan optree nie. Die owerheid het wel 'n verantwoordelikheid om kwaaddoeners te straf (Rom. 13:4). In hierdie opsig speel die owerheid 'n belangrike rol ten opsigte van immigrante wat die land onwettig binnekom. Die straf moet rekening hou met die aard van die oortreding, die omstandighede van die immigrante en die regte van die wettige burgers van die land.

\section{Beoordeling}

Uit die voorafgaande kan afgelei word dat werkers in beginsel die reg het om op enige plek op aarde te werk, met die oog daarop om vergoeding te verdien en hulleself en hulle afhanklikes te onderhou (Gen. 1:28). In 'n volmaakte bedeling sou daar genoeg werksgeleenthede vir die inwoners van elke land gewees het. Weens die sondeval gebeur dit egter dat daar nie oral genoeg werksgeleenthede is nie. Ook word werkers nie oral na behore vir hulle arbeid vergoed nie. Dit dwing werkers om elders (selfs in ander lande) werk te soek.

Op grond van die opdrag om die aarde te bewoon en te bewerk, is dit in beginsel nie verkeerd dat mense op enige plek ter wêreld die geleentheid soek om te werk nie. Die opdrag om te werk en die aarde te bewoon, is nie losstaande van reëlings wat owerhede met betrekking tot werkers en hulle arbeid tref nie. Owerhede het 'n besondere verantwoordelikheid teenoor die burgers van 'n land wat onder hulle jurisdiksie val. Die owerhede moet tot hulle beswil regeer (Rom 13:4), sodat hulle 'n rustige en stil lewe kan lei, waarin hulle hulself aan God kan toewy (1 Tim. 2:2). Bogenoemde impliseer dat 'n land se owerheid sake so behoort te orden dat die burgers van 'n land rustig hulle werk kan doen. In hierdie opsig rus daar 'n groot verantwoordelikheid op die owerhede om wettige werkers en werkgewers op so 'n manier te beskerm dat hulle nie deur onwettige immigrante benadeel word nie. Dit moet op so 'n manier gedoen word dat onwettige immigrante nie onmenslik behandel word nie. Wetgewing behoort tot die beswil van die wetsgehoorsame werkers (en werkgewers) van 'n land te wees.

By die beoordeling van die invloed van onwettige immigrante op die vergoeding wat werkers ontvang, is dit belangrik om daarop te let dat dit nie gaan oor wettige immigrante wat die land binnekom en op 'n aanvaarbare manier werk soek en vind nie. Onwettige immigrante is mense wat die wette oortree in die manier waarop hulle die land binnekom, werk bekom en hulleself selfs permanent vestig. Deur 
hulle onwettige optrede onderwerp hulle hulself nie aan die gesag wat God daargestel het nie.

Op die oog af mag dit lyk asof onwettige immigrasie summier veroordeel moet word, omdat onwettige immigrante op verskillende maniere nie aan die owerheid onderdanig is nie. Dit is egter nie so eenvoudig nie, omdat swak administrasie veroorsaak dat talle immigrante regtens as onwettig gedefinieer word, terwyl hulle die land wettig ingekom het en probeer om wettig in die land te wees. In hierdie opsig is dit belangrik dat die Departement van Binnelandse Sake en ander rolspelers moet toesien dat húlle nie die eintlike oorsaak is dat immigrante die wet oortree nie. Die beoordeling van onwettige immigrasie na Suid-Afrika word nog meer ingewikkeld in die lig van die botsing tussen onderdanigheid aan die owerheid (streng toepassing van wette rakende onwettige immigrante) en die nakoming van die liefdesgebod, wat onder meer bewoënheid teenoor armes en weerloses vereis. Hierdie spanning word geïllustreer deur die onwilligheid van die Suid-Afrikaanse regering om streng grensbeheer toe te pas (Anon., 2002:10; 2008:2) en daarmee toelaat dat immigrante onwettig die land binnekom (liefdesgebod), maar hulle dan daarna in hegtenis neem en repatrieer en werkgewers wat hulle in diens neem, swaar beboet (wetstoepassing).

Om bogenoemde teenstrydighede te voorkom, is dit belangrik dat oplossings gesoek word wat op verantwoordbare teologies-etiese uitgangspunte gegrond is. Die liefdesgebod behoort as vertrekpunt geneem te word. Dit behoort vergestalting te vind in wetgewing en optrede teenoor onwettige immigrante. Die wetgewing behoort die regte van die wettige burgers van die land op so 'n wyse te beskerm dat dit nie die menswaardigheid van onwettige immigrante aantas nie. Wetgewing moet daarom binne 'n aanvaarbare menseregtemodel ontwikkel word.

'n Basiese uitgangspunt behoort te wees dat alle mense in beginsel die reg het om op enige plek op aarde te kan werk. Dit impliseer dat owerhede van verskillende lande ten nouste met mekaar moet saamwerk om immigrasie tussen lande op 'n verantwoordbare manier te bestuur. Globalisasie, landsgrense wat nie die historiese woongebiede van inheemse inwoners na behore in berekening bring nie, die groter beweeglikheid van mense en die realiteit dat regerings dit al hoe moeiliker vind om deur wetstoepassing mense uit ' $n$ land te hou (vgl. Crush et al., 2006:2), maak die samewerking tussen owerhede nog meer noodsaaklik. 
Daar is toenemende konsensus dat, indien immigrasie behoorlik bestuur word deur die lande van oorsprong en die ontvangerlande, dit 'n positiewe ontwikkelingsimpak kan hê. ' $n$ Voorbeeld hiervan is die groot bedrae geld wat immigrante na hulle lande van oorsprong stuur. Dit verlig die druk vir toekomstige immigrasie. Wanneer immigrasie behoorlik bestuur word, behoort lande nie immigrasie as 'n probleem te beskou wat lande ekonomies, polities, sosiaal en kultureel raak nie. Immigrasie moet eerder sodanig gekanaliseer en bestuur word dat die positiewe uitwerking daarvan gemaksimaliseer word, veral op ekonomiese terrein (Williams \& Carr, 2006:1). Hierdie benadering verdien in die omstandighede tans ernstige oorweging. Indien dit reg bestuur word, kan die probleem van onwettige immigrasie op 'n manier hanteer word wat meer aan die bybelse beginsel van beskerming en hulpverlening aan weerloses voldoen.

Dit is van die grootste belang dat die regerings van suidelike Afrika se beleide ten opsigte van immigrasie met mekaar moet ooreenstem. Die beleide behoort op goeie beheer, deeglike bestuur en kliënt-georiënteerde diens gerig te wees (vgl. Crush et al., 2006:2). Die Immigrasiewet (SA, 2002) maak voorsiening dat 'n oorgrensowerheid ingestel kan word om die beweging in 'n bepaalde gebied te vergemaklik. Sulke oorgrensowerhede is nog nie ingestel nie en behoort aandag te geniet (Waller, 2006:4). Die aanbevelings van die Groenskrif rakende onwettige immigrante behoort ernstig oorweeg te word. Die Groenskrif (SA, 1997:11) beveel onder meer aan dat bona fide ekonomiese immigrante van ander SAOG-lande, wat nie permanent hier wil aanbly nie, meer geleentheid sal ontvang om deel te hê aan die Suid-Afrikaanse arbeidsmark.

Hoewel die moontlikheid bestaan dat ongeskoolde Suid-Afrikaners se werkgeleenthede in die gedrang kan kom, is daar nog nie onbetwisbare getuienis dat onwettige immigrante 'n negatiewe uitwerking op die werkloosheidskoers van Suid-Afrikaanse ongeskoolde werkers het nie. 'n Ondersoek wat in 2001-2002 deur die SAMP gedoen is, toon aan dat $60 \%$ van die respondente nog nooit gehoor het van iemand wat nie 'n werk gekry het omdat dit aan 'n vreemdeling toegeken is nie. Byna $90 \%$ van die respondente het self geen persoonlike ondervinding dat hulle 'n werkgeleentheid ontneem is wat aan 'n buitelander toegeken is nie (Crush \& Pendleton, 2004:19). Die implikasie hiervan is dat die owerheid nie teen onwettige immigrante behoort op te tree bloot op grond van die persepsie dat hulle plaaslike inwoners van werksgeleenthede ontneem nie. Talle onwettige immigrante help om werk te skep, omdat hulle Suid-Afrikaners in diens neem en produkte hier koop en dit dan uitvoer. 
Verdere navorsing wat op die uitwerking van onwettige immigrasie op die arbeidsmark konsentreer, is nodig (Waller, 2006:14). Navorsing tans toon aan dat baie onwettige immigrante geskool is en derhalwe kan help om die vaardigheidstekort in Suid-Afrika hok te slaan. Indien dit vir onwettige immigrante makliker gemaak word om in Suid-Afrika wettig te woon en te werk, kan dit bydra om die vaardigheidstekort in die land te verminder en ook die moontlike mededinging met ongeskoolde Suid-Afrikaners vir werkgeleenthede vermy. Die vrye beweging van burgers van die ECOWAS kan as voorbeeld dien hoe die oorgrensbeweging van mense in hierdie streek vergemaklik kan word. Dit kan voorkom dat mense onwettige in ander lande is (vgl. Adepoju, 2006:37).

Waar dit duidelik is dat onwettige immigrante sekere werkers in Suid-Afrika werksgeleenthede ontneem, behoort die Suid-Afrikaanse owerheid maatreëls in te stel om daardie spesifieke kategorieë inwoners te beskerm (vgl. Rom. 13:4). 'n Voorbeeld in hierdie verband is die groot getal buitelandse werkers uit die SAOG-lande wat in die negentigerjare amnestie ontvang het om in Suid-Afrika te woon en te werk. Waar hierdie werkers deel vorm van die aangewese groep werkers soos gedefinieer deur die Wet op Gelyke Indiensneming (SA, 1998), kwalifiseer hulle kragtens die beleid van regstellende aksie vir werk waarvan sekere Suid-Afrikaanse burgers uitgesluit word. In sulke gevalle behoort die Suid-Afrikaanse werkers voorkeur bo buitelandse werkers te kry.

Hoewel Suid-Afrika se regering 'n besondere verantwoordelikheid teenoor sy eie onderdane het, sluit dit nie die land se verantwoordelikheid teenoor inwoners van ander sukkelende lande uit nie. Die realiteit is egter dat Suid-Afrika self beperkte hulpbronne het, wat dit onmoontlik maak om ander lande se ekonomiese probleme (die hoofoorsaak van onwettige immigrasie) op te los (vgl. Anon., 2003: 15). Die ideaal waarna gestreef behoort te word, is om die oorsaak waarom werkers na Suid-Afrika stroom, te behandel. Suid-Afrika behoort ekonomiese groei in omringende lande aan te moedig en te ondersteun. Dit sal meer werksgeleenthede skep in die lande waaruit onwettige immigrante kom en hulle ontmoedig om na Suid-Afrika te immigreer. Die behandeling van die oorsake is nie so eenvoudig nie en vereis toegewyde optrede deur verskillende rolspelers.

Suid-Afrikaanse beleggers kan ook ' $n$ rol speel om onwettige immigrasie te ontmoedig. Daar is 'n noue verwantskap tussen ekonomiese ontwikkeling en immigrasie. Beleggings in buurlande wat werksgeleenthede skep, sal werkers daar ontmoedig om onwettig na Suid-Afrika te immigreer. Ekonomiese ongelykhede, armoede en 
politieke en sosiale onstabiliteit is faktore wat mense van elders na Suid-Afrika lok (SA, 1999:6).

Immigrante behoort self ook ' $n$ rol te speel om die noodsaak van onwettige immigrasie uit die weg te ruim. Hulle behoort byvoorbeeld hulle stemreg in die lande van hulle herkoms te gebruik om regeringsverteenwoordigers te kies wat sal toesien dat die arbeidsopset in hulle lande van burgerskap meer positief is.

'n Sterker roepingsbewustheid by onwettige immigrante is ook nodig, sodat hulle hulle vermoëns sal ontwikkel en gebruik om die lande van hulle herkoms te ontwikkel, en meer werksgeleenthede daar te skep. Waar kundige mense emigreer, dra dit by tot werkloosheid in die lande wat hulle verlaat (Vorster, 2008:29). Elke inwoner het die plig om sy eie vermoëns ter wille van homself en sy naaste aan te wend en die aarde waar hy woon te bewerk en te ontwikkel. So ' $n$ ingesteldheid kan bydra dat onwettige immigrante self werkskeppend in hulle lande van oorsprong sal optree. Vir so 'n ingesteldheid sal werkers tot die begrip moet kom dat hulle rentmeesters is wat die (arbeids-) wêreld in hulle eie lande kan verander (vgl. Van der Walt, 1999:117).

\section{Samevatting}

Die invloed wat onwettige immigrante op die Suid-Afrikaanse arbeidsmark het, is 'n komplekse en emosionele saak waarvoor daar nie eenvoudige oplossings beskikbaar is nie.

Onwettige immigrasie het in baie opsigte 'n negatiewe uitwerking op Suid-Afrika en sy arbeidsmark. Onwettige immigrante ding met plaaslike werkers mee vir skaars hulpbronne, openbare dienste en in sekere gevalle vir werksgeleenthede. Sommige is ook by kriminele aktiwiteite betrokke. Onwettige immigrante lewer egter ook 'n positiewe bydrae. Entrepreneurs neem Suid-Afrikaanse werkers in diens. Hulle bevorder indirek werkskepping met die koop van produkte in Suid-Afrika, wat dan buite die land se grense verkoop word.

In die soeke na 'n teologies-verantwoordbare oplossing behoort die volgende basiese uitgangspunte te geld: Enige mens het in beginsel die reg om op enige plek op aarde te woon en te werk. Vreemdelinge is verplig om ' $n$ land se wette te gehoorsaam. Vreemdelinge in 'n land behoort ook die geleentheid te hê om te kan werk om in hulle basiese behoeftes te voorsien. Dit impliseer egter nie dat hulle presies dieselfde regte en voorregte as 'n land se burgers moet hê nie. Die owerheid het die plig om na sy onderdane om te sien. Dit 
mag nie op so 'n wyse gedoen word dat vreemdelinge onmenslik behandel word nie.

Hoewel verskeie inisiatiewe onderneem is om onwettige immigrasie hok te slaan, was nie een daarvan geslaagd nie. Al die rolspelers sal ' $n$ bydrae moet lewer om die negatiewe invloed van onwettige immigrasie op die arbeidsterrein in Suid-Afrika teen te werk. Die rolspelers sluit die Suid-Afrikaanse owerheid, die owerhede van die onwettige immigrante se lande van herkoms, beleggers en die onwettige immigrante self in.

\section{Geraadpleegde bronne}

ADEPOJU, A. 2006. Leading issues in international migration in sub-Saharan Africa. (In Cross, C., Gelderblom, D., Roux, N. \& Mafukidze, J., eds. Views on migration in sub-Saharan Africa. Cape Town: HSRC. p. 25-47.)

AKOKPARI, J. 2007. Globalization, migration and challenges of development in Africa. (In Patterson, R., ed. African brain circulation: beyond the braindrain debate. Leiden: Brill. p. 59-86.)

ANON. 2000. 5 miljoen onwettiges in S.A. Beeld: 4, 8 Mrt.

ANON. 2002. Stop dit toe. Beeld: 10, 25 Jan.

ANON. 2003. Refugees put pressure on local resources. Sowetan: 15, 23 Jun.

ANON. 2008. Home affairs against tighter borders. The Mercury: 2, 10 Dec.

BHENGU, C. 2000. Deportees jump from train and flee. Sowetan: 3, 31 Mar.

CAMPBELL, E.K. 2002. Skills and brain drain and the movement of skilled migrants in Southern Africa. Papers read at the Workshop on Regional Integration, Poverty and South Africa's Proposed Migration Policy held in Pretoria on 23 April 2002. http://www.queensu.ca/samp/Conferences/ Agendas/Agenda7e.pdf Date of access: 4 Oct. 2008.

CARTER, C. \& HAFFAJEE, F. 1998. Immigrants are job makers, not job stealers. http://www.mg.co.za/mg/news/98sepl/14sep_immigrants.html Date of access: 21 Jul. 1999.

CRUSH, J., PEBERDY, S. \& WILLIAMS, V. 2006. International migration and good governance in the Southern African region. (Migration Policy Brief, no. 17.) http://www.queensu.ca/samp/sampresources/samppublications/ policybriefs/brief17.pdf Date of access: 4 Oct. 2008.

CRUSH, J. \& PENDLETON, W. 2004. Regionalizing xenophobia? Citizen attitudes to immigration and refugee policy in Southern Africa. http://www.queensu.ca/samp/sampresources/samppublications/policyserie s/Acrobat30.pdf Date of access: 4 Oct. 2008.

CRUSH, J. \& WILLIAMS, V. 2001. Making up the numbers: measuring "illegal immigration" to South Africa. (Migration Policy Brief, no. 3.) http://www.queensu.ca/samp/sampresources/samppublications/policybrief s/brief3.pdf Date of access: 4 Oct. 2008.

CRUSH, J. \& WILLIAMS, V. 2004. NEPAD, the city and the migrant: implications for urban governance. (Migration Policy Brief, no. 12.) http://www.queensu.ca/samp/sampresources/samppublications/policybrief s/brief12.pdf Date of access: 4 Oct. 2008. 
DE BEER, E.J. 2004. Die vergoeding vir arbeid in Suid-Afrika: 'n teologiesetiese studie. Potchefstroom: Noordwes-Universiteit. (Ph.D-proefskrif.)

DE BEER, E.J. 2008. 'n Teologies-etiese beoordeling van werkloosheid. In die Skriflig, 42(1):25-50.

DE VILLIERS, J.L. 1977. Die Handelinge van apostels. DI. 1. Kaapstad: NG Kerkuitgewers.

HANDMAKER, J. 2002. Evaluating refugee protection in South Africa. (Migration Policy Brief, no. 7.) http://www.queensu.ca/samp/samp resources/ samppublications/policybriefs/brief7.pdf Date of access: 4 Oct. 2008.

HIRSCHOWITZ, R. 2001. Methodology for census 2001 South Africa: applying lessons learnt from census '96. http://www.statssa.gov.za/asc2007/ WebsiteReports/SouthAfrica2.pdf Date of access: 4 Oct. 2008.

HOLLADAY, W.L. 1971. A Concise Hebrew and Aramaic Lexicon of the Old Testament. Leiden: Brill.

INTEGRATED REGIONAL INFORMATION NETWORKS 2007. South AfricaZimbabwe: report dismisses "human tsunami of migrants" claim. http://www.irinnews.org/report.aspx?ReportID=74143 Date of access: 4 Oct. 2008.

IRIN

see INTEGRATED REGIONAL INFORMATION NETWORKS

LANDAU, L. 2005. Migration, urbanisation and sustainable livelihoods in South Africa. (Migration Policy Brief, No. 15.) http://www.queensu.ca/samp/ sampresources/samppublications/policybriefs/brief15.pdf Date of access: 4 Oct. 2008.

LEKOTA, I. \& MPYE, S. 2000. Secure carriages "on the way". Sowetan: 3, 31 Mar.

MARTIN-ACHARD, R. 1984. רוג. (In Jenni, E. \& Westermann, C., Hrsg. Theologisches Handwörterbuch zum Alten Testament. Bd. 1. München: Kaiser. S. 409-412.)

MATSENA, D. 2002. For many Lindela just means a free ride back home. The Star: 6, 20 May.

MCDONALD, D.A., GAY, J., ZINYAMA, L., MATTES, R. \& DE VLETTER, F. 1998. Challenging xenophobia: myths and realities about cross-border migration in Southern Africa. (Migration Policy Series, no. 7.) http://www.queensu.ca/samp/sampresources/samppublications/policyserie s/Acrobat7.pdf Date of access: 4 Oct. 2008.

MCDONALD, D.A., MASHIKE, L. \& GOLDEN, C. 1999. The lives and times of African migrants \& immigrants in post-apartheid South Africa. (Migration Policy Series, no. 13.) http://www.queensu.ca/samp/sampresources/ samppublications/policyseries/Acrobat13.pdf Date of access: 4 Oct. 2008.

MOLAKENG, S. 2001. Firms to be fined R40 000 for alien workers. Sowetan: 12, 7 Aug.

PEBERDY, S. \& CRUSH, J. 1998. Trading places: cross-border traders and the South African informal sector. (Migration Policy Series, no. 6.) http://www.queensu.ca/samp/sampresources/samppublications/policyserie s/Acrobat6.pdf Date of access: 4 Oct. 2008. 
POSEL, D. 2003. Have migration patterns in post-apartheid South Africa changed? Paper prepared for the Conference on African Migration in Comparative Perspective in Johannesburg on 4-7 June 2003. http://pum.princeton.edu/pumconference/papers/1-Posel.pdf Date of access: 4 Oct. 2008.

PRETORIUS, E.A.C. 1988. Die brief van Jakobus. Kaapstad: NG Kerkuitgewers.

ROGERSON, C.M. 1997. International migration, immigrant entrepeneurs and South Africa's small enterprise economy. (Migration Policy Series, no. 3.) http://www.queensu.ca/samp/sampresources/samppublications/policyserie s/Acrobat3.pdf Date of access: 4 Oct. 2008.

ROGERSON, C.M. 1999. Building skills: cross-border migrants and the South African construction industry. (Migration Policy Series, no. 11.) http://www.queensu.ca/samp/sampresources/samppublications/policyserie s/Acrobat11.pdf Date of access: 4 Oct. 2008.

SA

SAMP

kyk SOUTH AFRICA

kyk SOUTHERN AFRICAN MIGRATION PROJECT

SOUTH AFRICA. 1998. Employment Equity Act, no. 55 of 1998. http://www.polity.org.za/govdocs/legislation/1998/act98-55.html Date of access: 10 Nov. 2001.

SOUTH AFRICA. 2002. Immigration Act, No. 13 of 2002. http://uscdn. creamermedia.co.za/assets/articles/attachments/00072_immigration.pdf Date of access: 4 Oct. 2008.

SOUTH AFRICA. Department of Home Affairs. 1997. Draft Green Paper on International Migration. Pretoria: Government Printer.

SOUTH AFRICA. Department of Home Affairs. 1999. White paper on international migration. http://www.info.gov.za/whitepapers/1999/migrate. htm Date of access: 4 Oct. 2008.

SOUTHERN AFRICAN MIGRATION PROJECT. 2001. Making up the numbers: Measuring "illegal immigrants" to South Africa. (Migration Policy Brief, no.3.) http://www.queensu.ca/samp/sampresources/samppublications/ policybriefs/brief3.pdf Date of access: 4 Oct. 2008.

TEVERA, D. \& ZINYAMA, L. 2002. Zimbabweans who move: perspectives on international migration in Zimbabwe. (Migration Policy Series, no. 25.) http://www.queensu.ca/samp/sampresources/samppublications/policyserie s/Acrobat25.pdf Date of access: 4 Oct. 2008.

VAN DER WALT, B.J. 1999. Kultuur, lewensvisie en ontwikkeling: 'n ontmaskering van die gode van onderontwikkelde Afrika en die oorontwikkelde Weste. Potchefstroom: PU vir $\mathrm{CHO}$.

VORSTER, J.M. 2004. Ethical perspectives on human rights. Potchefstroom: Potchefstroom Theological Publications.

VORSTER, J.M. 2008. Die vreemdeling in ons midde. Die Kerkblad, 111(3214):28-29.

WALLER, L. 2006. Irregular migration to South Africa during the first ten years of democracy. (Migration policy brief, no. 19.) http://www.queensu. $\mathrm{ca} / \mathrm{samp} /$ sampresources/samppublications/policybriefs/brief19.pdf Date of access: 4 Oct. 2008. 
WILLIAMS, V. \& CARR, L. 2006. The draft protocol on the facilitation of movement of persons in SADC. (Migration Policy Brief, no. 18.) http://www.queensu.ca/samp/sampresources/samppublications/policybrief s/brief18.pdf Date of access: 4 Oct. 2008.

\section{Kernbegrippe:}

arbeid

migrasie

onwettige immigrasie

\section{Key concepts:}

illegal immigration

labour

migration 
